Agro-Science Journal of Tropical Agriculture, Food, Environment and Extension Volume 19 Number 4 (October 2020) pp. 18 - 23

ISSN 1119-7455

\title{
MANAGEMENT OF AQUATIC PLANTS AND THEIR CONTRIBUTIONS TO FISHERIES PRODUCTION IN IKERE-GORGE, ISEYIN, OYO STATE, NIGERIA
}

\author{
${ }^{* 1}$ Ajagbe S.O., ${ }^{2}$ Soaga J.A., ${ }^{3}$ Olunloyo A.A., ${ }^{4}$ Odewo S.A. and ${ }^{1}$ Udaghe O.M. \\ ${ }^{1}$ Department of Wildlife \& Ecotourism, Forestry Research Institute of Nigeria, \\ P.M.B. 5054, Jericho, Ibadan, Oyo State, Nigeria \\ ${ }^{2}$ Department of Forestry \& Wildlife, Federal University of Agriculture, Abeokuta, \\ P.M.B. 2240, Abeokuta, Ogun State, Nigeria \\ ${ }^{3}$ Department of Agricultural Technology, Federal College of Forestry, Ibadan \\ ${ }^{4}$ Department of Forest Conservation \& Protection, Forestry Research Institute of Nigeria, \\ P.M.B. 5054, Jericho, Ibadan, Oyo State, Nigeria \\ *Corresponding author's email: stephenolua@gmail.com
}

\begin{abstract}
Aquatic plants are important in freshwater ecosystems. They provide food, shelter, spawning and nursery grounds for fish. They are usually found at the littoral parts of freshwater ecosystems. The abundance, distribution and diversity of aquatic plant of Ikere-gorge, Iseyin, Nigeria were examined between January 2017 and December 2018. There are twelve fishing villages in Ikere-gorge and four villages were randomly selected. Aquatic plants were sampled and collected with the help of hired fishermen. The collected aquatic plant samples were identified at the Forest Herbarium of the Forestry Research Institute of Nigeria with appropriate keys. This work identified 13 families and 23 species of aquatic plants. Cyperaceae family recorded the highest (4) number of individual species while Salvinia molesta had the highest abundance in all the sampling sites. The ecological classification of the aquatic plants showed that 14 species are emergent; 7 species floating and 3 species submerged. Site C had the most abundance (9220) of aquatic plants, followed by site $D(8490)$, site $B(8130)$ and site $A(7940)$. The gamma $(\gamma)$ and beta ( $\beta)$ diversities were 23 and 0.01 respectively. The alpha ( $\alpha$ ) diversity included Dominance (0.08), Simpson (0.92) and Shannon-Wiener (2.72) respectively. These results show that Salvinia molesta and Najas guadalupensis are the most and least abundant aquatic plants in Ikere-gorge respectively; which may be due to their ecological status. Moreover, management of aquatic plants is an integral part of fisheries management for sustainable fisheries. Therefore, their management is essential for the maintenance of aquatic biodiversity.
\end{abstract}

Key words: aquatic plants, diversity, emergent, floating, submerged

\section{INTRODUCTION}

According to USAID (2015), freshwater diversity includes the species that depend upon freshwater ecosystems for one or more components of their life cycles, including plants, insects, amphibians, reptiles, fishes, crustaceans, mammals, and birds. Likewise, CBD (2016) explained that freshwater biodiversity is simply biodiversity associated with inland waters. But since all terrestrial animals and plants depend on fresh water, the boundaries between aquatic and terrestrial are blurred. At the species level, inland water biodiversity generally includes all life forms that depend upon inland water habitat for things other than simply drinking (or transpiration in plants). Besides the obvious life living within water itself(e.g., fish), this also includes many "terrestrial" species of animals (e.g. waterbirds), semi-aquatic animals (e.g. hippopotamus, crocodiles, beaver) and plants (e.g. flooded forest, mangroves, vegetation associated with the margins of water bodies). The majority of amphibians, for example, breed in fresh water. Cook (1990) defined aquatic plants as plants with photosynthetic parts that are permanently or temporarily submerged or floating in water and visible to the human eye. Aquatic plants are important components of the aquatic ecosystem especially freshwater ecosystem contributing to the aquatic biodiversity. Moderate abundance of aquatic plants in the freshwater ecosystem supports fish production; they provide shelter or habitat, spawning ground and even food for some fish species and other aquatic organisms (Dienye, 2015). Valley et al. (2004) explained the importance and functions of aquatic plant for fish population and productive fisheries. Aquatic plants support primary production, stabilizing sediments, maintaining water clarity, and providing quality habitat for zooplankton, macro invertebrates, and numerous fish species. 
However, aquatic plants may become a nuisance and a challenge to the management of freshwater ecosystem causing economic as well as ecological losses by adversely affecting the aquatic ecosystem, (Narasimha and Benarjee, 2016). Studies on aquatic plants are rare, especially on aquatic plants of Ikere-gorge. This study is important to give baseline information on species composition, abundance and diversity of aquatic plants in Ikere-gorge. This information is vital to the management of aquatic plants and improves their provision of habitats, food items and recruitment grounds for aquatic organisms.

\section{MATERIALS AND METHODS \\ Study Site}

Ikere-gorge is a multipurpose dam located at Ikere village, about $28 \mathrm{~km}$, North East of Iseyin in Oyo State. Ikere-gorge is located between longitude $8^{\circ} 10^{\prime}$ and $8^{\circ} 20^{\prime} \mathrm{N}$ and latitude $3^{\circ} 40^{\prime}$ and $3^{\circ} 50^{\prime} \mathrm{E}$ (Figure 1). Along the bank of the dam are distributed forest and savanna trees and aquatic grasses and shrubs. The dam experiences frequent current as a result of wind that blows on it from time to time. Sometimes, the current results to wave action which spreads across the dam and it could be violent particularly during the raining season (Kehinde and Ayoade, 2012). Ikere-gorge took its source from Sepeteri about $40 \mathrm{~km}$ to Ikere through Asamu and Alagbon. Ikere-gorge has Ogun River as its major tributary and River Amaka, River Oowe and River Owu as its minor tributaries.

There are 12 fishing villages in Ikere-gorge. Four sampling sites were selected from Ikere-gorge using stratified random sampling method. The fishing villages were divided into four strata for easy access according to their geographical location and proximity to each other. From each sampling site, one fishing village was chosen randomly for sampling to make a good representation. The selected sampling sites (fishing villages) included Site A Asamu (N 8 13' 54.828" E $\left.3^{\circ} 47^{\prime} 00.696^{\prime \prime}\right)$, Site B Agatu (N 8 09' 51. 972" E 3 44' 57.642"), Site C Spillway (N $8^{\circ} 11^{\prime} 53.760^{\prime \prime}$ E $\left.3^{\circ} 44^{\prime} 51.810^{\prime \prime}\right)$ and Site D Irawote (N $8^{\circ} 14^{\prime} 01.170^{\prime \prime}$ E $3^{\circ} 42^{\prime} 47$. $802^{\prime \prime)}$. The locations of the sampling sites and other fishing villages were documented using global positioning system (GPS). The selected sampling sites were sampled for four days consecutively in the first week of every month for a period of 24 months (January 2017 to December 2018).

\section{Sampling, Preservation and Identification of Aquatic Plant Species}

Aquatic plants were assessed by taking the inventory of floating, emergent and submerged plants of the dam. The sampling method of Adesina et al. (2011) was adopted for this study. Sampling plots were established in each fishing village. A 10 $\mathrm{x} 10 \mathrm{~m}$ plot was laid to facilitate a complete littoral and open water plant species data collection. A fisherman was employed in each of the selected fishing village for the collection of the aquatic plants located in the dam. The samples were collected by moving the canoe slowly through the littoral zone of the water in a zigzag manner. Submersed species and emergent species found along the shore of the dam were collected. The depth of the water was also observed. Aquatic plants were collected in the dam with their flowers, seeds and roots by hand and sampling rakes. These samples were rinsed and preserved using plant press. They were later taken to the Forestry Research Institute of Nigeria for proper identification. Identification of aquatic plant species was done using identification keys such as: Akobundu and Agyakwa (1998) and web based manual. GPS was used to take the locations where the aquatic plant samples were collected.

\section{Data Analysis \\ Relative Density}

It is the proportion contribution of individual aquatic species to the total population in the sample. It was computed with the formula:

$$
\mathrm{RD}=\mathrm{Si} / \mathrm{N} \times 100
$$

where $\mathrm{RD}$ is relative density, $\mathrm{Si}$ is population of individual species, and $N$ is total population of species.

\section{Frequency of Occurrence}

This is the number of plots individual aquatic plant species was recorded among the sampling plots. Hence, it was calculated using the formula of Lare-Tier II (2010):

$$
\mathrm{S} / \mathrm{N} \times 100
$$

where $\mathrm{S}$ is the number of points where the specie is present, and $N$ is the total number of plots surveyed.

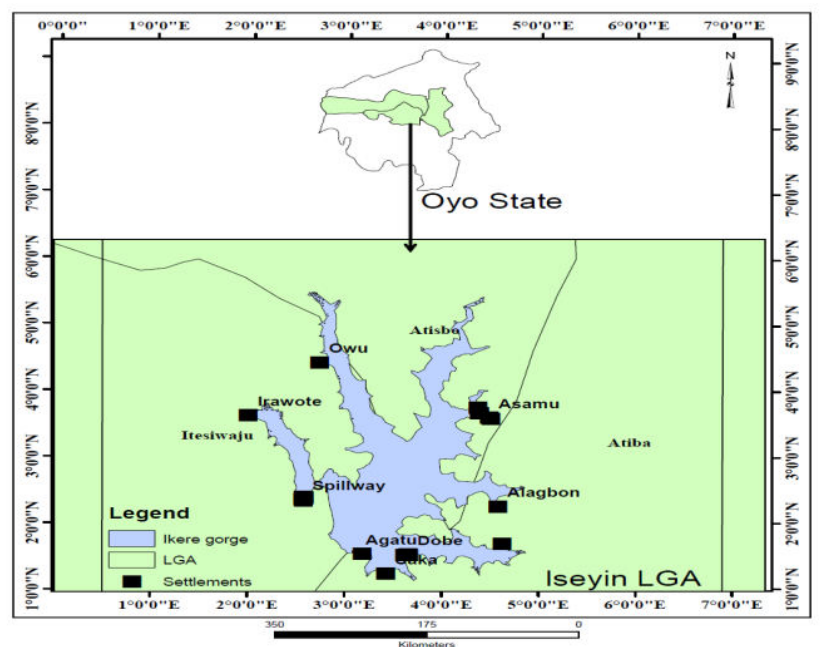

Figure 1: Map of Ikere-Gorge (showing some fishing villages), Iseyin, Oyo State, Nigeria 


\section{Diversity Indices}

Aquatic diversity was determined by different diversity indices using Palaeontological Statistics (PAST) and $R$ statistical package (Odulate et al., 2017; Hammer et al., 2001).

i. Shannon-Weiner Diversity Index (Mörsdorf, 2015):

$$
H=-\Sigma P i \ln P i \text {. }
$$

where $H$ is Shannon-Weiner index (the uncertainty of species identity), $P i$ is ni/ $\mathrm{N}, n i$ is number of individuals of each species in the sample, and $N$ is total number of individuals of all species in the sample.

ii. Simpson's Dominance Index (Hossain et al., 2012):

$$
\left.\lambda=\sum \mathrm{p}_{\mathrm{i}}^{2} \lambda=\underline{\text { ni(ni-1) }}\right) \mathrm{N}(\mathrm{N}-1)
$$

The value of $\lambda$ ranges between 0 and 1 . When $\lambda$ is 0 , it signifies infinite (maximum or highest) diversity, but 1 signifies no diversity in the population.

iii. Simpson's Index of Diversity (D), also called Gini coefficient.

$$
\mathrm{D}=1-\frac{\sum \mathrm{ni}(\mathrm{ni}-1)}{\mathrm{N}(\mathrm{N}-1)=1-\lambda}
$$

Likewise, the value of $\mathrm{D}$ is between 0 and 1 . When $\mathrm{D}$ is 0 , it signifies no diversity in the population, but 1 is infinite (highest or maximum) diversity.

\section{RESULTS}

This study identified 13 families and 23 species of aquatic plants in Ikere-gorge, Iseyin, Oyo State, Nigeria. Cyperaceae family recorded the highest (4) number of individual species. They are Carex autro-africana, Cyperus dives, Rynchospora corymbosa and Scirpus articulatus. Nymphaeaceae and poaceae family recorded 3 individual species of aquatic plants each. They were Nymphaea caerulea, Nymphaea lotus and Nymphaea nouchalia (Nymphaeaceae); while family Poaceae were Echinochloa pyramidalis, Andropogon tectorum and Phragmites australis. The families of Convolvulaceae, Onagraceae and Ploygonaceae had two species each, while the families of Araceae, Ceratophyllaceae, Fabaceae, Hydrocharitaceae, Salviniaceae and Sphenocleaceae had one species each (Table 1). Likewise, Table 1 and Figure 2 show that $58 \%$ of the aquatic plants reported were emergent amounted, $29 \%$ are floating and $13 \%$ are submerged.

The results show that a floating macrophyte; Salvinia molesta had the highest abundance in all the sampling sites. But Najas guadalupensis was observed to have the least abundance with relative density of 0.27 . Moreover, the abundance of other aquatic plants was diverse in the sampling sites. In site $\mathrm{A}$, the most abundant aquatic plants were Potamogeton schweinfurthii, Andropogon tectrum,

\begin{tabular}{|c|c|c|c|}
\hline Family & $\begin{array}{l}\text { Plant } \\
\text { species }\end{array}$ & $\begin{array}{l}\text { Common } \\
\text { name }\end{array}$ & Ecology \\
\hline Araceae & $\begin{array}{l}\text { Pistia } \\
\text { stratiotes }\end{array}$ & $\begin{array}{l}\text { Water } \\
\text { lettuce }\end{array}$ & Floating \\
\hline Ceratophyllaceae & $\begin{array}{l}\text { Ceratophyllum } \\
\text { demersum }\end{array}$ & Hornwort & Submerged \\
\hline Convolvulaceae & $\begin{array}{l}\text { Ipomoea } \\
\text { aquatica } \\
\text { Ipomoea } \\
\text { asarifolia }\end{array}$ & $\begin{array}{l}\text { Water } \\
\text { spinach, } \\
\text { Ginger } \\
\text { leaf }\end{array}$ & $\begin{array}{l}\text { Emergent } \\
\text { Emergent }\end{array}$ \\
\hline \multirow[t]{4}{*}{ Cyperaceae } & $\begin{array}{l}\text { Carex } \\
\text { autro-africana }\end{array}$ & $\begin{array}{l}\text { Cat's } \\
\text { tail sedge }\end{array}$ & Emergent \\
\hline & $\begin{array}{l}\text { Cyperus } \\
\text { dives }\end{array}$ & $\begin{array}{l}\text { Giant } \\
\text { sedge }\end{array}$ & Emergent \\
\hline & $\begin{array}{l}\text { Rynchospora } \\
\text { corymbosa }\end{array}$ & & Emergent \\
\hline & $\begin{array}{l}\text { Scirpus } \\
\text { articulatus }\end{array}$ & & Emergent \\
\hline Fabaceae & $\begin{array}{l}\text { Neptunia } \\
\text { oleracea }\end{array}$ & $\begin{array}{l}\text { Water } \\
\text { mimosa }\end{array}$ & Floating \\
\hline Hydrocharitaceae & $\begin{array}{l}\text { Najas } \\
\text { guadalupensis }\end{array}$ & $\begin{array}{l}\text { Water } \\
\text { nymph }\end{array}$ & Submerged \\
\hline \multirow[t]{3}{*}{ Nymphaeaceae } & $\begin{array}{l}\text { Nymphaea } \\
\text { caerulea }\end{array}$ & blue lotus & Floating \\
\hline & $\begin{array}{l}\text { Nymphaea } \\
\text { lotus }\end{array}$ & $\begin{array}{l}\text { White } \\
\text { lotus }\end{array}$ & Floating \\
\hline & $\begin{array}{l}\text { Nymphaea } \\
\text { nouchalia }\end{array}$ & $\begin{array}{l}\text { Blue } \\
\text { lotus }\end{array}$ & Floating \\
\hline \multirow[t]{2}{*}{ Onagraceae } & $\begin{array}{l}\text { Ludwigia } \\
\text { decurrens }\end{array}$ & $\begin{array}{l}\text { Upright } \\
\text { primose }\end{array}$ & Emergent \\
\hline & $\begin{array}{l}\text { Ludwigia } \\
\text { stolonifer }\end{array}$ & $\begin{array}{l}\text { Creeping } \\
\text { ludwigia }\end{array}$ & Floating \\
\hline Salviniaceae & $\begin{array}{l}\text { Salvinia } \\
\text { molesta }\end{array}$ & $\begin{array}{l}\text { Water } \\
\text { varing }\end{array}$ & Floating \\
\hline \multirow[t]{2}{*}{ Polygonaceae } & $\begin{array}{l}\text { Persicaria } \\
\text { senegalensis }\end{array}$ & & Emergent \\
\hline & $\begin{array}{l}\text { Polygonum } \\
\text { senegalense }\end{array}$ & & Emergent \\
\hline Sphenocleaceae & $\begin{array}{l}\text { Sphenoclea } \\
\text { zeylanica }\end{array}$ & Wedgewort & Emergent \\
\hline Poaceae & $\begin{array}{l}\text { Echinochloa } \\
\text { pyramidalis }\end{array}$ & $\begin{array}{l}\text { Antelope } \\
\text { grass }\end{array}$ & Emergent \\
\hline Poaceae & $\begin{array}{l}\text { Phragmites } \\
\text { australis }\end{array}$ & $\begin{array}{l}\text { Common } \\
\text { weed }\end{array}$ & Emergent \\
\hline Poaceae & $\begin{array}{l}\text { Andropogon } \\
\text { tectrum }\end{array}$ & $\begin{array}{l}\text { Horse } \\
\text { grass }\end{array}$ & Emergent \\
\hline Potamogetonaceae & $\begin{array}{l}\text { Potamogeton } \\
\text { schweinfurthii }\end{array}$ & Pondweed & Submerged \\
\hline
\end{tabular}
Phragmites australis and Echinochloa pyramidalis.
Table 1: Checklist of species composition of aquatic plants of Ikere-Gorge, Iseyin

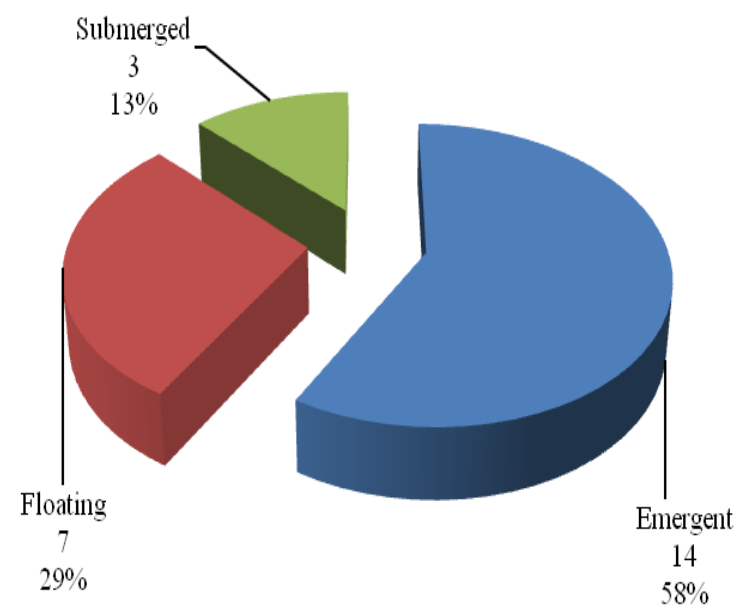

Figure 2: Ecological status of aquatic plants in Ikeregorge, Iseyin, Oyo State, Nigeria 
In site $\mathrm{B}$, the most abundant aquatic plants were Echinochloa pyramidalis, Phragmites australis, Andropogon tectrum and Ludwigia stolonifer. In site $\mathrm{C}$, the most abundant aquatic plants were Echinochloa pyramidalis, Ludwigia stolonifer, Scirpus articulatus and Cyperus dives. In site D, the most abundant aquatic plants were Echinochloa pyramidalis, Ludwigia stolonifer, Cyperus dives and Andropogon tectrum (Table 2). Likewise, Table 2 shows that only Neptunia oleracea had $50 \%$ frequency of occurrence, while Ipomea aquatica, Ceratophyllum demersum, Carex autro-africana, Percicaria senegalensis, Sphenoclea zeylanica, and Najas guadalupensis had $75 \%$ of frequency of occurrence and other aquatic plants had $100 \%$ of frequency of occurrence in Ikere-gorge.
Emergent and submerged aquatic plants in the littoral zone are identified in Ikere-gorge as spawning and nursery grounds for fish. They provide suitable shelter for fish fry, fingerlings and juvenile; because water current is moderated by the aquatic plants. Likewise, leaves, stems and fruits of some aquatic plants like Nymphaea spp. are edible for both fish and man (Plate 1). Therefore, herbivorous and omnivorous fish such as Cichlidae and Clariidae usually come to the littoral zone to forage. Occasionally, some predatory fish also come to prey on these fish. This also provides opportunity for fisher folks to set their traps (fishing gears) under these aquatic plants to catch (Plate 2). Therefore, as the fish grow and mature they migrate out of the littoral zone.

Table 2: Spatial abundance of aquatic plants of Ikere-gorge, Oyo State, Nigeria

\begin{tabular}{|c|c|c|c|c|c|c|c|}
\hline Plant Species & Site A & Site B & Site C & Site D & Ikere & RD & FO $(\%)$ \\
\hline Salvinia molesta & 1020 & 960 & 1430 & 1370 & 4780 & 14.15 & 100 \\
\hline Echinochloa pyramidalis & 1120 & 860 & 960 & 1060 & 4000 & 11.84 & 100 \\
\hline Scirpus articulatus & 680 & 620 & 720 & 580 & 2600 & 7.70 & 100 \\
\hline Phragmites australis & 730 & 860 & 520 & 490 & 2600 & 7.70 & 100 \\
\hline Ludwigia stolonifer & 510 & 680 & 760 & 640 & 2590 & 7.67 & 100 \\
\hline Andropogon tectrum & 380 & 820 & 650 & 610 & 2460 & 7.28 & 100 \\
\hline Cyperus dives & 560 & 510 & 720 & 630 & 2420 & 7.16 & 100 \\
\hline Pistia stratiotes & 380 & 470 & 490 & 510 & 1850 & 5.48 & 100 \\
\hline Potamogeton schweinfurthii & 330 & 460 & 520 & 420 & 1730 & 5.12 & 100 \\
\hline Rynchospora corymbosa & 440 & 340 & 470 & 390 & 1640 & 4.85 & 100 \\
\hline Nymphaea nouchalia & 310 & 290 & 420 & 380 & 1400 & 4.14 & 100 \\
\hline Nymphaea lotus & 310 & 350 & 380 & 320 & 1360 & 4.03 & 100 \\
\hline Nymphaea caerulea & 330 & 280 & 250 & 290 & 1150 & 3.40 & 100 \\
\hline Polygonum senegalense & 150 & 120 & 210 & 170 & 650 & 1.92 & 100 \\
\hline Ludwigia decurrens & 110 & 140 & 160 & 210 & 620 & 1.84 & 100 \\
\hline Ipomoea asarifolia & 110 & 100 & 140 & 50 & 400 & 1.18 & 100 \\
\hline Ipomoea aquatica & 130 & 80 & 160 & 0 & 370 & 1.10 & 75 \\
\hline Ceratophyllum demersum & 150 & 110 & 0 & 80 & 340 & 1.01 & 75 \\
\hline Carex autro-africana & 130 & 0 & 50 & 80 & 260 & 0.77 & 75 \\
\hline Persicaria senegalensis & 0 & 50 & 90 & 70 & 210 & 0.62 & 75 \\
\hline Sphenoclea zeylanica & 50 & 0 & 30 & 70 & 150 & 0.44 & 75 \\
\hline Neptunia oleracea & 0 & 0 & 40 & 70 & 110 & 0.33 & 50 \\
\hline Najas guadalupensis & 10 & 30 & 50 & 0 & 90 & 0.27 & 75 \\
\hline Total & 7940 & 8130 & 9220 & 8490 & 33780 & 100.00 & \\
\hline
\end{tabular}

RD: Relative Density; FO: Frequency of Occurrence

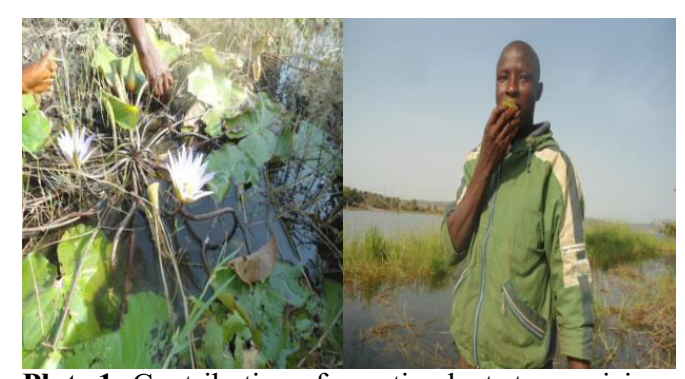

Plate 1: Contribution of aquatic plants to provision of food in Ikere-gorge, Iseyin, Oyo State

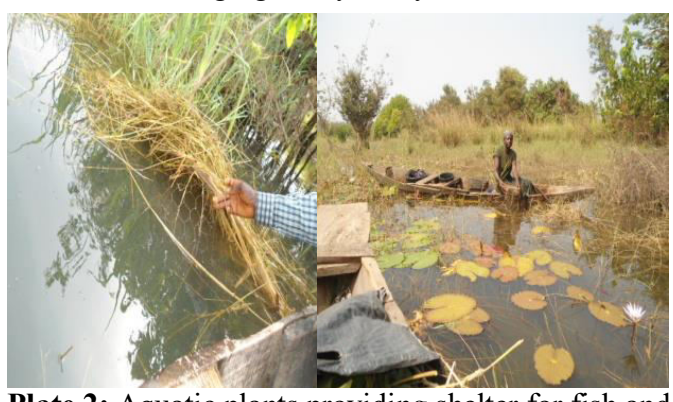

Plate 2: Aquatic plants providing shelter for fish and fishing ground for fisher folks in Ikere-gorge, Iseyin, Oyo State, Nigeria
Table 3: Diversity indices of aquatic plants of Ikeregorge, Iseyin, Oyo State, Nigeria

\begin{tabular}{lccccc}
\hline & Site A & Site B & Site C & Site D & Ikere \\
\hline Individuals & 7940 & 8130 & 9220 & 8490 & 33780 \\
Gamma & 23 & 23 & 23 & 23 & 23 \\
Beta $\left(\beta_{\mathrm{P}}\right)$ & 0.12 & 0.12 & 0.12 & 0.12 & \\
Beta $\left(\beta_{\mathrm{D}}\right)$ & 0.91 & 0.91 & 0.91 & 0.91 & \\
Taxa_S & 21 & 20 & 22 & 21 & 23 \\
Dominance_D & 0.08 & 0.08 & 0.08 & 0.08 & 0.08 \\
Simpson_1-D & 0.92 & 0.92 & 0.92 & 0.92 & 0.92 \\
Shannon_H & 2.75 & 2.71 & 2.75 & 2.72 & 2.76 \\
Evenness_e^H/S & 0.74 & 0.75 & 0.71 & 0.73 & 0.69 \\
\hline
\end{tabular}

Table 3 shows the diversity indices of aquatic plants in Ikere-gorge. The results show that gamma $(\gamma)$, proportional and differentiation diversity were 23, 0.10 and 0.91 respectively. The alpha diversity for site A, site B, site C and site D were 21, 20, 22 and 21 respectively. Likewise, Table 4 shows the values of other alpha diversity indices. It shows that dominance and Simpson indexes were constant at all sites; dominance is 0.08 and Simpson index was 0.92. Shannon Wiener for site A and site C was 2.75 , while site $B$ and site $D$ were 2.71 and 2.72 respectively. The Evenness for site A, B, C and $\mathrm{D}$ were $0.74,0.75,0.71$ and 0.73 respectively. 


\section{DISCUSSION}

Aquatic plants provide shelter, spawning ground; security and food for aquatic organisms especially fish. This study identified Nymphaea spp. as an edible aquatic plant. Narasimha and Benarjee (2016) reported that aquatic plants serve as a good source of food to mankind and animals (including water birds) and for aquatic wildlife conservation practices. Okayi et al. (2013) reported that aquatic macrophytes may serve as food for fish, shelter to fish, serve as spawning ground, provide food and shelter to water fowls, improve aesthetic values, and provide materials for curative therapy as ethnobotanic. Pinese et al. (2015) observed that aquatic plants allow the emergence of a variety of niches and microhabitats, supporting a highly diverse zooplankton community around them.

This study identified 23 species belonging to 13 families of aquatic plants in Ikere-gorge, Iseyin, Oyo State, Nigeria. Dienye and Olopade (2017) identified 20 species of aquatic plants representing 13 families in Oyan Lake, Ogun State, Nigeria. Dienye (2015) reported 10 families of macrophyte (12 species) in New Calabar River, Niger Delta. Narasimha and Benarjee (2016) recorded 25 macrophytes from littoral and sub-littoral zones of the tank at four stations in Nagaram tank of Warangal district, Telangana State. Ghosh and Biswas (2015) recorded 45 genera of macrophytes in Ganga River Basin. Likewise, this study showed that Cyperaceae family recorded the highest (4) number of individual species. This is in agreement with Dienye and Olopade (2017) who reported that Cyperaceae and Poaceae families had the highest species with four species each in Oyan Lake, Ogun State, Nigeria. Also, Dienye (2015) that Cyperaceae had the highest species with three species in New Calabar River, Niger Delta, Nigeria.

Cyperaceae family can be found in almost all types of habitats with exception of few as Antarctica (Košnar, 2013). Although, this study identified Cyperaceae family as emergent aquatic plants, it can also be found in freshwater ecosystem as floating and submerged aquatic plants. This is due to their capacity to absorb excess nutrients especially phosphorus and nitrogen and become often dominant. They play an important role in primary productivity and support hydrological cycle. They provide habitats for faunal diversity. Their fruits and, sometimes, shoots and tubers are important food for many aquatic and amphibious animals. Likewise, they are used in weaving mats, baskets, screens, and even sandals because of their strong, fibrous stems and leaves (Mishra et al., 2016; Encyclopaedia Britannica 2013). In addition, Mishra et al. (2016) identified other ecological functions perform by Cyperaceae family. They stabilize water flow and control erosion. They develop and produce peat and peat soil. They can be used as health indicator in wetlands; recycling nutrients; removing sediments and heavy metals. The presence of heavy metals in freshwater ecosystem affects physiological and metabolic activities of fish. Idowu et al. (2020) identified Oreochromis niloticus as one of fish affected by heavy metals.
Salvinia molesta is a freshwater invasive species of aquatic plants. It was the most abundance aquatic plants in all the sampling sites in Ikere gorge. It has the ability to grow rapidly. It can quickly cover the entire surface of water body with a thick mat of vegetation; thereby limiting exchange of oxygen and light within the water column. This can negatively affect the biodiversity and abundance of freshwater species, including fish and submersed aquatic plants. Salvinia molesta invasions can alter wetland ecosystems and cause wetland habitat loss (Richard and Ramey, 2007; BioNET-EAFRINET, N.D.). Najas guadalupensis was observed to have the least abundance. It is a delicate plant. It can break easily. Its population is vulnerable to the movement of fish and other aquatic animals. Emergent aquatic plants are found at the littoral zone in aquatic ecosystem. They are the most visible among aquatic plants. This study identified 14 species (58\%) of emergent aquatic plants. This shows relative encroachment of littoral zone and reduction of the core area of the gorge as a result of accumulation of silts and detritus from the catchments area (Ghosh and Biswas, 2015).

This is in agreement with the report of Ahmad et al. (2015) and Adesina et al. (2011). But, Dienye (2015) reported that among the 12 species sampled, 10 were grouped as emergent, two as floating and none was submerged. Ghosh and Biswas (2015) reported that emergent plants showed the largest number, followed by submerged, free floating, and rooted floating leaved in Ganga River Basin.

Though submerged aquatic plants are important in aquatic ecosystems they are the least abundant in this study. This agrees Yamaki and Yamamuro (2013). They reported that submerged plants are often scarce, nevertheless they are considered to be the most suitable refuge against predators and form of foraging habitat for small fishes; they are most preferred by fishes. Submerged plants are adapted to living with their roots submerged by water. They grow completely below water surface. They are found far from littoral zone that are dominated by emergent plants; into the core part of the lake. Submerged plants create important habitat and food sources for wildlife; they filter and trap soil and absorb nutrient. Valley et al. (2004) reiterated the management of submerged aquatic plants in which any alteration to submerged aquatic plants will invariably have some effect on a lake's fish community. Some floating aquatic plants identified in this study such as Pistia stratiotes (water lettuce) and Ipomea aquatica (water spinach) were also identified by Okayi et al. (2013). This study reported that Shannon_H varied between 2.71 and 2.76. This is in agreement with the result of Dienye (2015) who reported Shannon Weinner of 2.72. Ghosh and Biswas (2015) reported that Shannon_H index values ranges between 0 and 5 . This shows that there is moderate diversity of aquatic plants in Ikere-gorge. This is confirmed in the values of Dominance (D) and Simpson $(1-$ D) obtained in 
this study. These values imply that the probability of picking the same species in the same population of aquatic plant in Ikere-gorge with or without replacement is 0.08. But, Ekpo et al. (2016) reported that Shannon-Wiener Index of aquatic macrophyte community of a riparian stream in Odot, Niger Delta, Nigeria varied between 2.29 and 2.64.

\section{CONCLUSION}

Aquatic plants are integral components of aquatic ecosystem. Their abundance, distribution and diversity are governed by the environmental variables at all levels including air, terrestrial and aquatic. Najas guadalupensis was observed to have the least abundance. But, an invasive species, Salvinia molesta was the most abundant aquatic plant in all the sampling sites in Ikere gorge. Its population must be controlled for sustainability of aquatic biodiversity of Ikere-gorge. Some of these aquatic plants are edible for fish and even human. Species composition, abundance and diversity of aquatic plants of Ikeregorge showed their contribution to the biodiversity of the gorge. However, almost aquatic plants identified in this study provide support for fish production and improve water quality. Some of these aquatic plants are edible for fish and human being. Moreover, management of aquatic plants is an integral part of fisheries management for sustainable fisheries and they are essential for the maintenance of aquatic biodiversity in the aquatic ecosystem.

\section{REFERENCES}

Adesina G.O., Akinyemiju O.A. and Muoghalu J.I. (2011). Checklist of the aquatic macrophytes of Jebba Lake, Nigeria. Ife J. Sci., 13 (1), 93-103

Ahmad U., Parveen S., Hasan T. and Bhat B.N. (2015). Diversity of aquatic macrophytes of Aligarh, U.P. India. Int. J. Current Microbiol. Appl. Sci., 4 (4), 494-505

Akobundu I.O. and Agyakwa C.W. (1998). A handbook of West African Weeds. International Institute of Tropical Agriculture, Ibadan, 56

BioNET-EAFRINET. N.D. Regional Salvinia molesta (Kariba Weed). https://keys.lucidcentral.org/keys/v3/ eafrinet/weeds/key/weeds/Media/Html/Salvinia_molesta_ (Kariba Weed).htm

Convention on Biological Diversity (CBD) (2016). Inland Waters Biodiversity - Why is it Important? Secretariat of the Convention on Biological Diversity https:/www.cbd.int/waters/importance/default.shtml

Cook C.D.K. (1990). Aquatic Plant Book. SBP Academic, The Hague, Netherlands, 110-112

Dienye H.E. and Olopade O.A. (2017). Distribution and abundance of aquatic plants of Oyan Lake, Ogun State, Nigeria. Bonorowo Wetlands, 7 (1), 11-16

Dienye H.E. (2015). Species diversity of macrophytes of the New Calabar River, Niger Delta, Nigeria, Int. J. Fisheries Aquatic Studies, 20153 (1), 409-413

Ekpo I.E., Essien-Ibok M.A. and Ekpenyong U.R. (2016). Abundance, distribution and biotic indices of aquatic macrophyte community of a riparian stream in Odot, Niger Delta, Nigeria, FUTA J. Res. Sci., 12 (2), 195 - 205

Encyclopaedia Britannica (2013). Cyperaceae plant family: Economic and ecological importance. https://www.britannica.com/plant/Cyperaceae/Chara cteristic-morphological-features
Ghosh D. and Biswas J.K. (2015). Biomonitoring macrophytes diversity and abundance for rating aquatic health of an oxbow lake ecosystem in Ganga River Basin. Am. J. Phytomed. Clinical Therapeutics, 3 (10), 602-621

Hammer O., Harper D.A.T. and Ryan P.D. (2001). PAST: Paleontological Statistics Software Package for education and data analysis, Palaeontologia Electronica 1-9. www.palaeo-electronica.org

Hossain M.S., Das N.G., Sarker S. and Rahaman M.Z. (2012). Fish diversity and habitat relationship with environmental variables at Meghna river estuary, Bangladesh. Egyptian J. Aquatic Res., 38, 213-226

Idowu A.A., Popoola O.C., Alani J.O., Ipadeola A. and Nwekoyo V.E. (2020). Toxicity effect of Kigelia africana aqueous extract on the haematology and histopathology of juvenile Nile Tilapia (Oreochromis niloticus). Agro-Science, 19 (1), 37-42. DOI: https://dx.doi.org/10.4314/as.v19i1.6

Kehinde F.O. and Ayoade A.A. (2012). Limnological features of Ikere Gorge Reservoir, Iseyin southwestern Nigeria: Plankton composition and abundance. J. Biodiversity Environ. Sci., 2 (6), 20-31

Košnar J. (2013). Biosystematic Studies in the Family Cyperaceae. Ph.D. Thesis Series, No. 7. University of South Bohemia, Faculty of Science, School of Doctoral Studies in Biological Sciences, České Budějovice, Czech Republic, 139 pp.

Mishra S., Tripathi A., Tripathi D.K. and Chauhan D.K. (2016). Role of sedges (Cyperaceae) in wetlands, environmental cleaning and as food material: Possibilities and future perspectives. In: Azooz M.M. and Ahmad P. John (eds.), Plant-Environment Interaction: Responses and Approaches to Mitigate Stress. John Wiley \& Sons, Ltd., 328

Mörsdorf M.A. (2015). Effects of local and regional drivers on plant diversity within tundra landscapes. $\mathrm{PhD}$ dissertation, Faculty of Life and Environmental Sciences, University of Iceland, 145

Narasimha R.K. and Benarjee G. (2016). Diversity and distribution of macrophytes in Nagaram tank of Warangal district, Telangana state. Int. J. Fisheries Aquatic Studies, 4 (1), 270-275

Odulate D.O., Omoniyi I.T., Alegbeleye W.O., George F.A. and Dimowo B.O. (2017). Water quality in relation to plankton abundance and diversity in river Ogun, Abeokuta, Southwestern Nigeria. Int. J. Environ. Health Engineering, 6 (3), 1-8

Okayi R.G., Daku V. and Mbata F.U. (2013). Some aquatic macrophytes and water quality parameters of River Guma, Benue, Nigeria. Nigerian J. Fisheries Aquaculture, 1 (1), 25-30

Pinese O.P., Pinese J.F. and Del Claro K. (2015). Structure and biodiversity of zooplankton communities in freshwater habitats of a Vereda Wetland Region, Minas Gerais, Brazil. Acta Limnologica Brasiliensia, 1, 1-15

Richard A. and Ramey V. (2007). Invasive and Nonnative Plants You Should Know - Recognition Cards. University of Florida-IFAS Publication \# SP 431

USAID (2015). Biodiversity and development handbook, 280. www.usaid.gov/biodiversity

Valley R.D., Cross T.K. and Radomski P. (2004). The role of submersed aquatic vegetation as habitat for fish in Minnesota lakes, including the implications of nonnative plant invasions and their management. Minnesota Dept. of Natural Resources Special Publ. 160, 24

Yamaki A. and Yamamuro M. (2013). Floating-leaved and emergent vegetation as habitat for fishes in a eutrophic temperate lake without submerged vegetation. Limnology, 14, 257-268 